\title{
Deoxyverrucosidin, a Novel GRP78/BiP Down-regulator, Produced by Penicillium sp.
}

\author{
Soo-Jin Choo, Hae-Ryong Park, In-Ja Ryoo, Jong-Pyung Kim, Bong-Sik Yun, \\ Chang-Jin Kim, Kazuo Shin-ya, Ick-Dong Yoo
}

Received: December 14, 2004 / Accepted: February 14, 2005

(C) Japan Antibiotics Research Association

\begin{abstract}
Glucose-regulated protein 78 (GRP78) resides in endoplasmic reticulum (ER) and plays a role in protecting tumor cells against the toxic effects of anticancer agents. During the search for down-regulators of GRP78 using a reporter gene (luciferase) assay system, we isolated a novel compound designated as deoxyverrucosidin (1), a congener of verrucosidin (2), from Penicillium sp. and identified it as a down-regulator of the grp 78 gene. The structure of 1 was determined by mainly ESI-mass and twodimensional NMR spectra. 1 dose-dependently inhibited the expression of GRP78 promoter with an $\mathrm{IC}_{50}$ of $30 \mathrm{nM}$.
\end{abstract}

Keywords glucose-regulated protein 78 (GRP78), anticancer agents, deoxyverrucosidin, Penicillium sp.

GRP78 resides in the endoplasmic reticulum (ER) and functions as a molecular chaperone by aiding the folding and transport of proteins it associates with transiently as they traverse the ER [1-3]. Strikingly, pathological conditions such as tumor growth correlate with GRP78 overexpression [4]. This could be partly caused by the activation of grp gene expression through glucose starvation, acidosis and hypoxia, which are hallmarks of the microenvironment of poorly vascularized solid tumors [5]. These correlations are supported by the observed increases in the levels of GRP78 expression in fibrosarcomas, in which GRP78 expression strongly correlates with tumor growth $[6,7]$. The observation that GRP78 plays a role in protecting tumor cells against intracellular-mediated cytotoxicity and from the toxic effects of anticancer agents in vitro suggests that the induction of GRP78 may protect tumor cells in vivo [8]. Thus, substances that directly down-regulate GRP78 induction might be of potential use in cancer therapy.

During the course of our screening program for chaperone modulators using a reporter gene (luciferase) assay system, we have isolated a novel compound designated as deoxyverrucosidin (1) from Penicillium sp. and identified it as a down-regulator of the grp 78 gene (Fig. 1). In this paper, we report upon the isolation, structure elucidation and biological activities of $\mathbf{1}$. The producing strain Penicillium sp. was cultivated in a seed medium consisting of glucose $2 \%$, yeast extract $0.2 \%$, peptone $0.5 \%, \mathrm{MgSO}_{4} \cdot 7 \mathrm{H}_{2} \mathrm{O} 0.05 \%$ and $\mathrm{KH}_{2} \mathrm{PO}_{4} 0.1 \%$ (pH 5.6) for 3 days at $28^{\circ} \mathrm{C}$ on a rotary shaker. The seed culture was transferred into a production medium composed of wheat bran $-\mathrm{H}_{2} \mathrm{O}(1: 1)$ and fermentation was carried out in $500 \mathrm{ml}$ flasks for 7 days at $28^{\circ} \mathrm{C}[9,10]$.

The mycelium obtained from 10 liters culture was extracted with acetone and the extract was concentrated in vacuo to eliminate acetone. The aqueous resultant was extracted with ethyl acetate. The organic layer was concentrated and applied to a column of silica gel eluted with hexane - ethyl acetate $(10: 1 \sim 1: 1)$. The active eluate was then chromatographed on a Sephadex LH-20 column
I.-D. Yoo (Corresponding author), S.-J. Choo, I.-J. Ryoo, J.-P. Kim, B.-S. Yun, C.-J. Kim: Laboratory of Antioxidants, Korea Research Institute of Bioscience and Biotechnology, Daejeon 305333, Korea, E-mail: idyoo@kribb.re.kr
H.-R. Park: Division of Food Science and Biotechnology, College of Engineering, Kyungnam University, Masan 631-701, Korea K. Shin-ya: Institute of Molecular and Cellular Bioscience, The University of Tokyo, Bunkyo-ku, Tokyo 113-0032, Japan 
<smiles>COc1c(C)c(/C(C)=C/C(C)=C/C(C)=C/[C@@]2(C)O[C@H](C)[C@]3(C)O[C@@H]2O3)oc(=O)c1C</smiles>

Deoxyverrucosidin (1)

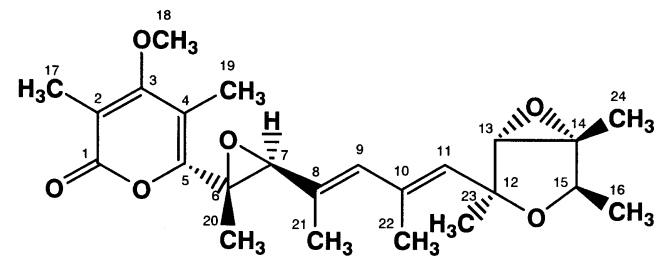

Verrucosidin (2)

Fig. 1 Structures of deoxyverrucosidin (1) and verrucosidin (2). eluted with $\mathrm{MeOH}$. Finally, pure deoxyverrucosidin (1), a congener of verrucosidin (2), was obtained by HPLC using a YMC-pack ODS-A column $(4.6 \mathrm{~mm}$ i.d. $\times 150 \mathrm{~mm})$ eluted with $60 \% \mathrm{CH}_{3} \mathrm{CN}$ [11].

The UV spectra of $\mathbf{1}\left(\lambda_{\max } \mathrm{nm}\right.$ in MeOH: 278,326$)$ and $\mathbf{2}$ $\left(\lambda_{\max } \mathrm{nm}\right.$ in $\left.\mathrm{MeOH}: 238,295\right)$ indicated that two compounds have different chromophores. The molecular formula of 1 was established as $\mathrm{C}_{24} \mathrm{H}_{32} \mathrm{O}_{5}$ by ESI-MS spectrum in combination with ${ }^{1} \mathrm{H}$ and ${ }^{13} \mathrm{C}$ NMR data. The ${ }^{1} \mathrm{H}$ and ${ }^{13} \mathrm{C}$ NMR spectra of $\mathbf{1}$ exhibited signals from 14 protons and 24 carbons. A heteronuclear multiple-quantum coherency (HMQC) experiment established all one-bond ${ }^{1} \mathrm{H}-{ }^{13} \mathrm{C}$ connectivities as shown in Table 1. A COSY experiment revealed two spin networks to generate partial structures $\mathbf{A}$ and $\mathbf{B}$ (Fig. 2). The heteronuclear multiplebond correlation (HMBC) spectrum displayed ${ }^{1} \mathrm{H}^{-13} \mathrm{C}$ longrange couplings from methyl protons $20-\mathrm{H}\left(\delta_{\mathrm{H}} 2.07\right)$ to $\mathrm{C}-5$ $\left(\delta_{\mathrm{C}} 159.0\right)$, C-6 $\left(\delta_{\mathrm{C}} 127.4\right)$ and C-7 $\left(\delta_{\mathrm{C}} 139.9\right)$, from methyl protons $21-\mathrm{H}\left(\delta_{\mathrm{H}} 1.97\right)$ to $\mathrm{C}-7\left(\delta_{\mathrm{C}} 139.9\right), \mathrm{C}-8\left(\delta_{\mathrm{C}}\right.$

Table $1{ }^{1} \mathrm{H}$ and ${ }^{13} \mathrm{C}$ NMR data for deoxyverrucosidin and verrucosidin in chloroform- $d_{1}$

\begin{tabular}{|c|c|c|c|c|}
\hline \multirow{2}{*}{ Position } & \multicolumn{2}{|c|}{ Deoxyverrucosidin } & \multicolumn{2}{|c|}{ Verrucosidin } \\
\hline & $\delta_{\mathrm{C}}(\mathrm{ppm})$ & $\delta_{\mathrm{H}}(\mathrm{ppm})$ & $\delta_{\mathrm{C}}(\mathrm{ppm})$ & $\delta_{\mathrm{H}}(\mathrm{ppm})$ \\
\hline 1 & 165.5 & & 165 & \\
\hline 2 & 110 & & 111 & \\
\hline 3 & 168.5 & & 167.8 & \\
\hline 4 & 109 & & 111 & \\
\hline 5 & 159 & & 155.9 & \\
\hline 6 & 127.4 & & 60.7 & \\
\hline 7 & 139.9 & $6.08(\mathrm{~s})$ & 64.7 & 3.49 (s) \\
\hline 8 & 134 & & 127.7 & \\
\hline 9 & 136.3 & 5.87 (s) & 131.6 & 5.87 (s) \\
\hline 10 & 132 & & 127.7 & \\
\hline 11 & 133.4 & 5.51 (s) & 133 & 5.47 (s) \\
\hline 12 & 80 & & 80 & \\
\hline 13 & 67.5 & 3.45 (s) & 67.4 & 3.43 (s) \\
\hline 14 & 67.4 & & 67.4 & \\
\hline 15 & 76.7 & $4.14(q, J=6.8 \mathrm{~Hz})$ & 76.7 & $4.13(q, J=6.8 \mathrm{~Hz})$ \\
\hline 16 & 18.8 & $1.21(\mathrm{~d}, J=6.8 \mathrm{~Hz})$ & 18.8 & $1.20(\mathrm{~d}, J=6.8 \mathrm{~Hz})$ \\
\hline 17 & 10.3 & 2.06 (s) & 10.4 & 2.05 (s) \\
\hline 18 & 60.2 & 3.83 (s) & 60 & 3.84 (s) \\
\hline 19 & 11.8 & 2.01 (s) & 9.2 & 2.05 (s) \\
\hline 20 & 16.7 & $2.07(\mathrm{~d}, J=1.2 \mathrm{~Hz})$ & 15.6 & $1.43(\mathrm{~d}, J=1.8 \mathrm{~Hz})$ \\
\hline 21 & 18.6 & 1.97 (br) & 15.3 & $1.91(\mathrm{~s})$ \\
\hline 22 & 18.5 & 1.97 (br) & 18.5 & $1.96(\mathrm{~s})$ \\
\hline 23 & 21.9 & 1.44 (s) & 21.9 & 1.43 (s) \\
\hline 24 & 13.8 & 1.48 (s) & 13.8 & 1.48 (s) \\
\hline
\end{tabular}

Chemical shifts in ppm from TMS as internal standard.

${ }^{1} \mathrm{H}$ and ${ }^{13} \mathrm{C}$ NMR were measured at $400 \mathrm{MHZ}$ and $100 \mathrm{MHz}$, respectively. 


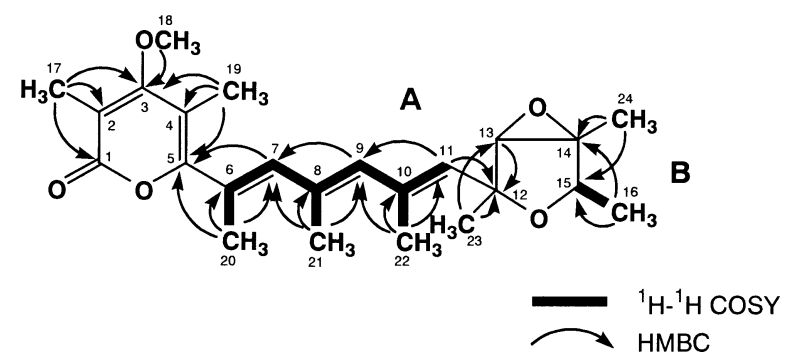

Fig. $2{ }^{1} \mathrm{H}^{-1} \mathrm{H}$ COSY and $\mathrm{HMBC}$ analysis of $\mathbf{1}$.

$134.0)$ and $\mathrm{C}-9\left(\delta_{\mathrm{C}} 136.3\right)$ and from methyl protons $22-\mathrm{H}$ $\left(\delta_{\mathrm{H}} 1.97\right)$ to $\mathrm{C}-9\left(\delta_{\mathrm{C}} 136.3\right), \mathrm{C}-10\left(\delta_{\mathrm{C}} 132.0\right)$ and C-11 $\left(\delta_{\mathrm{C}}\right.$ 133.4), thus establishing the existence of a triene moiety (Fig. 2). The ${ }^{13} \mathrm{C}$ chemical shifts of five downfield signals corresponding to $\mathrm{C}-1\left(\delta_{\mathrm{C}} 165.5\right), \mathrm{C}-2\left(\delta_{\mathrm{C}} 110.0\right), \mathrm{C}-3\left(\delta_{\mathrm{C}}\right.$ $168.5), \mathrm{C}-4\left(\delta_{\mathrm{C}} 109.0\right)$ and $\mathrm{C}-5\left(\delta_{\mathrm{C}} 159.0\right)$ were well matched to those of an $\alpha$-pyrone unit [12-14]. Two singlet methyl protons of $17-\mathrm{H}\left(\delta_{\mathrm{H}} 2.06\right)$ and $19-\mathrm{H}\left(\delta_{\mathrm{H}} 2.01\right)$ exhibited HMBC correlations to their adjacent carbons in the $\alpha$-pyrone moiety, as shown in Fig. 2. Additionally, methoxy protons $18-\mathrm{H}\left(\delta_{\mathrm{H}} 3.83\right)$ revealed ${ }^{1} \mathrm{H}^{13}{ }^{13} \mathrm{C}$ longrange coupling to a quaternary carbon $\mathrm{C}-3\left(\delta_{\mathrm{C}} 168.5\right)$, indicating the connection between methoxyl group and $\mathrm{C}-3$ position in the $\alpha$-pyrone substructure. The long-rang couplings from methyl protons $19-\mathrm{H}\left(\delta_{\mathrm{H}} 2.01\right)$ to $\mathrm{C}-5\left(\delta_{\mathrm{C}}\right.$ 159.0), from methyl protons $20-\mathrm{H}\left(\delta_{\mathrm{H}} 2.07\right)$ to $\mathrm{C}-5$ and from olefin proton $7-\mathrm{H}\left(\delta_{\mathrm{H}} 6.08\right)$ to $\mathrm{C}-5$ indicated a connection between partial structure $\mathbf{A}$ and an $\alpha$-pyrone moiety. The long-range couplings from methyl protons 16$\mathrm{H}\left(\delta_{\mathrm{H}} 1.21\right)$ to $\mathrm{C}-14\left(\delta_{\mathrm{C}} 67.4\right)$ and $\mathrm{C}-15\left(\delta_{\mathrm{C}} 76.7\right)$ and from singlet methyl protons $24-\mathrm{H}\left(\delta_{\mathrm{H}} 1.48\right)$ to $\mathrm{C}-14\left(\delta_{\mathrm{C}} 67.4\right)$ and $\mathrm{C}-15\left(\delta_{\mathrm{C}} 76.7\right)$ linked the quaternary carbon $\mathrm{C}-14$ to partial structure B (Fig. 2). ${ }^{1} \mathrm{H}-{ }^{13} \mathrm{C}$ long-range couplings from methyl protons $23-\mathrm{H}\left(\delta_{\mathrm{H}} 1.44\right)$ to $\mathrm{C}-11\left(\delta_{\mathrm{C}} 133.4\right) \mathrm{C}-$ $12\left(\delta_{\mathrm{C}} 80.0\right)$ and $\mathrm{C}-13\left(\delta_{\mathrm{C}} 67.5\right)$, from an oxygenated methine proton $13-\mathrm{H}\left(\delta_{\mathrm{H}} 3.45\right)$ to $\mathrm{C}-12\left(\delta_{\mathrm{C}} 80.0\right)$ and from an olefin proton $11-\mathrm{H}\left(\delta_{\mathrm{H}} 5.51\right)$ to $\mathrm{C}-12\left(\delta_{\mathrm{C}} 80.0\right)$ connected the quaternary carbon $\mathrm{C}-12$ to partial structure $\mathbf{A}$ (Fig. 2). By the process of elimination, two oxygenated carbons C-13 $\left(\delta_{\mathrm{C}} 67.5\right)$ and C-14 $\left(\delta_{\mathrm{C}} 67.4\right)$ should form an epoxide ring. Stereochemistry of tetrahydrofuran in $\mathbf{1}$ was proposed to be same as that of verrucosidin by identical chemical shift values and coupling constant of both compounds.

Biological activity of $\mathbf{1}$ and $\mathbf{2}$ were evaluated by reporter gene assay system utilizing luciferase gene. In brief, HT 1080 cells were transformed with luciferase gene under the control of grp 78 promoter and the cells $(20,000$ in each well of 96-well plates) were incubated for 8 hours and treated for 18 hours with various concentrations of $\mathbf{1}$ or $\mathbf{2}$ in the presence or absence of the 2-DG. Firefly luciferase activity was determined using the luciferase assay kit. As expected, treatment with 2-DG resulted in a 4-fold increase of grp 78 promoter activity in HT1080 cells. $\mathbf{1}$ and $\mathbf{2}$ dosedependently inhibited the expression of GRP78 promoter with $\mathrm{IC}_{50}$ of $30 \mathrm{nM}$ and $25 \mathrm{nM}$, respectively. These results indicate that $\mathbf{1}$ and $\mathbf{2}$ are specific inhibitors of the GRP78 promoter under low glucose conditions. Thus, it is hoped that these compounds are chemotherapeutically active against solid tumors, and/or that it can be used as a specific tool in studies addressing the molecular mechanisms of mammalian ER stress response. Detailed studies on biological activities are under the investigation.

Acknowledgement This work was supported by a grant of the National Research Laboratory program (to I. D. Yoo) from the Korean Ministry of Science and Technology.

\section{References}

1. Kaufman RJ. Stress signaling from the lumen of the endoplasmic reticulum: coordination of gene trasnscriptional and translational controls. Gene Dev 13: 1211-1233 (1999)

2. Yoshida H, Haze K, Yanagi H, Yura T, Mori K. Identification of the cis-acting endoplasmic reticulum stress response element responsible for transcriptional induction of mammalian glucose-regulated proteins. Involvement of basic leucine zipper transcription factors. J Biol Chem 273: 33741-33749 (1998)

3. Roy B, Lee AS. The mammalian endoplasmic reticulum stress response element consists of an evolutionarily conserved tripartite structure and interacts with a novel stress-inducible complex. Nucleic Acids Res 27: 1437-1443 (1999)

4. Little E, Ramakrishnan M, Roy B, Gazit G, Lee AS. The glucose-regulated proteins (GRP78 and GRP94): functions, gene regulation and applications. Crit Rev Eukaryot Gene Expr 4: 1-18 (1994)

5. Gazit G, Hung G, Chen X, Anderson WF, Lee AS. Use of the glucose starvation inducible grp 78 promoter in suicide gene therapy of murine fibrosarcoma. Cancer Res 59: 3100-3106 (1999)

6. Park HR, Tomida A, Sato S, Tsukumo Y, Yun J, Yamori T, Hayakawa Y, Tsuruo T, Shin-ya K. Effect of tumor cells of blocking survival response to glucose deprivation. J Natl Cancer Inst 96: 1300-1310 (2004)

7. Sausville EA. Versipelostatin: Unfolded an unsweetened death. J Natl Cancer Inst 96: 1266-1267 (2004)

8. Reddy RK, Mao C, Baumeister P, Austin RC, Kaufman RJ, Lee AS. Endoplasmic reticulum chaperone protein GRP78 protects cells from apoptosis induced by topoisomerase inhibitors. J Biol Chem 278: 20915-20924 (2003)

9. Oh SU, Yun BS, Lee SJ, Kim JH, Yoo ID. Atroviridins A C 
and neoatroviridins $\mathrm{A} \sim \mathrm{D}$, novel peptaibol antibiotics produced by Trichoderma atroviride F80317. I. Taxonomy, fermentation, isolation and biological activities. J Antibiot 55: 557-564 (2002)

10. Kim JP, Kim BK, Yun BS, Ryoo IJ, Lee CH, Lee IK, Kim WG, Lee SK, Pyun YR, Yoo ID. Melanocins A, B and C, new melanin synthesis inhibitors produced by Eupenicillium shearii. I. Taxonomy, fermentation, isolation and biological properties. J Antibiot 56: 993-999 (2003)

11. Hodge RP, Harris CM, Harris TM. Verrucofortine, a major metabolite of Penicillium verrucosum var. cyclopium, the fungus that produces the mycotoxin verrucosidin. J Nat Prod
51: 66-73 (1988)

12. Ganguli M, Burka LT, Harris TM. Structural studies of the mycotoxin verrucosidin. J Org Chem 49: 3762-3766 (1984)

13. Hatakeyama S, Sakurai K, Numata H, Ochi N, Takano S. A novel chiral route to substituted tetrahydrofurans, total synthesis of (+)-verrucosidin and formal synthesis of (-)citreoviridin. J Am Chem Soc 110: 5201-5203 (1988)

14. Hanaki N, Link JT, MacMillan DWC, Overman LE, Trankle WG, Wurster JA. Stereoselection in the prins-pinacol synthesis of 2,2-disubstituted 4-acyltetrahydrofurans. Enantioselective synthesis of (-)-citreoviral. Org Lett 2: 223-226 (2000) 